\title{
QUEEN'S
UNIVERSITY
BELFAST
}

\section{The inside story: A survey of social work students' supervision and learning opportunities on placement}

Cleak, H., Roulston, A., \& Vreugdenhil, A. (2016). The inside story: A survey of social work students' supervision and learning opportunities on placement. British Journal of Social Work. https://doi.org/10.1093/bjsw/bcv117

Published in:

British Journal of Social Work

Document Version:

Peer reviewed version

Queen's University Belfast - Research Portal:

Link to publication record in Queen's University Belfast Research Portal

Publisher rights

Copyright The Author 2016. Published by Oxford University Press on behalf of The British Association of Social Workers. All rights reserved. This is a pre-copyedited, author-produced PDF of an article accepted for publication in British Journal of Social Work following peer review. The version of record is available online at doi: 10.1093/bjsw/bcv117.

\section{General rights}

Copyright for the publications made accessible via the Queen's University Belfast Research Portal is retained by the author(s) and / or other copyright owners and it is a condition of accessing these publications that users recognise and abide by the legal requirements associated with these rights.

Take down policy

The Research Portal is Queen's institutional repository that provides access to Queen's research output. Every effort has been made to ensure that content in the Research Portal does not infringe any person's rights, or applicable UK laws. If you discover content in the Research Portal that you believe breaches copyright or violates any law, please contact openaccess@qub.ac.uk. 
The inside story: A survey of social work students' supervision and learning opportunities on placement

\section{Abstract}

Practice learning accounts for half of the content of the Bachelor of Social Work degree course requirements in Northern Ireland in their field education programs and share a professional and ethical responsibility with practice teachers to provide appropriate learning environments to prepare students as competent and professional practitioners. The accreditation standards for practice learning require the placement to provide students with regular supervision and exposure to a range of learning strategies, but there is little research that actually identifies the types of placements offering this learning and the key activities provided. This paper builds on an Australian study and surveys social work students in two programs in Northern Ireland about their exposure a range of learning activities, how frequently they were provided and how it compares to what is required by the Northern Ireland practice standards. The results indicated that, although most students were satisfied with the supervision and support they received during their placement, the frequency of supervision and type of learning activities varied according to different settings, year levels and who provided the learning opportunities.

Introduction

Internationally, social work field education programs, like many other professional courses, must provide appropriate learning environments that enable students to apply classroom learning and to actively engage and reflect on professional activities (Australian Association of Social Workers [AASW], 2012; Furness and Gilligan, 2004). Practice learning is universally acknowledged in the literature as the profession's 'gatekeeper' by transmitting core social work skills, knowledge and values to emerging graduates and to prepare them as competent and professional practitioners (Bogo, et al., 2002; Wayne et al., 2010). 
Practice learning has moved to centre stage with growing recognition that an increasingly complex client group requires a well-trained and well-skilled professional workforce. Over the past 10 years, in England, Wales and Northern Ireland, government requirements regarding the accreditation and training of practice teachers and models of assessment have been implemented in an attempt to improve practice learning (Furness and Gilligan, 2005) and to provide assurance to the industry that professional social workers are 'fit for practice' (Bogo et al., 2006; Hay and O’Donoghue, 2009; Wilson et al., 2008). The College of Social Work (2012, p.11) quality framework emphasises the need for 'regular and sufficient supervision of work performance' and access to complex work opportunities to prepare students for statutory aspects of the role. More recent reports (Narey, 2014; CroisdaleAppleby, 2014) make recommendations for the allocation, provision and quality assurance working regarding practice learning, all of which are already being met through current monitoring by the NISCC (NISCC, 2014). In Australia, the current and projected shortages in the health and human service sectors have activated Commonwealth and State government initiatives to increase the number of undergraduate students and to build capacity in the field to offer quality placements. Similarly, in Canada, the number of universities offering both undergraduate and graduate social work programs is increasing (Regehr, 2013; Bogo, 2006).

Practice teaching relies on agency-based social workers who are allocated as field instructors to assist students in achieving the educational objectives of the field program. The literature overwhelmingly reports that the role of these practice teachers remain central to student learning (Bogo, 2006; Lefevre, 2005) as well their exposure to a range of appropriate learning and assessment tasks (Furness and Gilligan, 2004). At the same time, changes in the health and welfare field have resulted in increased caseloads and higher acuity cases for social workers which has undermined their ability to the required level of supervision for students 
(Globerman and Bogo, 2002). Indeed, the current economic-driven climate often results in supervision being more task-focussed with limited opportunities of integrating theory into practice (Chinnery and Beddoe, 2011, p. 128) and therefore compromising the experience of the individual student (Bellinger, 2010). The Review of the Degree (DHSSPSNI, 2009) highlighted challenges for practice learning agencies in being able to sustain a sufficient supply of appropriate placements to meet the agreed standards, which include that all students complete one placement in a statutory social work agency, and a childcare placement, and that all final placements must be in a setting with an onsite social work practitioner. These pressures necessitate social work programs to find creative means for ensuring that high quality placement opportunities are available for larger numbers of students and that social work agencies must ensure that they can provide good quality, real life learning opportunities as well as appropriate supervision (DHSSPSNI, 2010).

Review of the Literature

Models of supervision

The principal model for practice learning used in the United Kingdom, the United States and Australia, relies heavily on the one-to-one relationship between the student and a suitably qualified social worker, called a 'practice teacher', a 'practice educator', or a 'supervisor'. Social work students consistently report that the supervisory relationship is the key to their learning and the literature has found it predicts satisfaction with all aspects of the field experience (Bogo, 2006; Fortune et al., 2001; Knight, 2000). When there is no qualified practice teacher in a setting, a long-arm practice and an on-site supervisor share the tasks. The on-site supervisor is largely responsible for placement management, case supervision and formative feedback, and the 'long-arm', 'offsite' or 'external supervisor' is primarily accountable for reflective learning, direct teaching and assessment (Lefevre, 2005). Social 
workers are recruited and trained to undertake these roles and can supervise several students at a time which can help to address the shortage of placements and alleviate some of the pressures on agency social workers. This model offers a number of advantages, including increased objectivity, greater opportunities to link theory and practice and opening up newer and more creative fields (Cleak, Hawkins \& Hess, 2000) but it has also been suggested that 'long-arm’ practice teachers have a greater reliance on information provided by third parties and may experience problems in accessing information about students’ performance (Furness and Gilligan, 2004). Further questions about the students’ learning arise as to whether the lack of clearly defined social work roles adversely affects the development of social work identity (Zuchowski, 2015; Plath, 2003).

This was confirmed in an Australian study by Cleak \& Smith (2012), which analysed responses to a questionnaire administered to 263 undergraduate social work students after they had completed their placement in order to identify the models of supervision and student satisfaction with their learning experiences and the supervision received on placement. The study identified that just over half of the placements used the traditional one student to one social work supervisor model, or singleton model, plus another model, where two or more social workers were involved in the professional supervision of the student. High levels of dissatisfaction were reported by those students who received external social work supervision. Results suggest that students are more satisfied across all aspects of the placement where there is a strong on-site social work presence.

The result of the considerable pressure on the practice community to educate and supervise more students, without additional resources or reductions in workloads (Muskat et al., 2012) has seen the appearance of newer models of supervision, including group supervision and a 
rotational model where students are placed in one agency but rotate between two or three related areas, each with different supervisors (Bogo, 2006; Regehr, 2013). This latter model requires more research on the educational outcomes as current studies are quite narrow, lack control groups and are limited to a few fields of practice (Gough and Wilks, 2010).

\section{Learning activities on placement}

Students develop competence in performing social work functions through undertaking educationally-focused activities while on placement. However, practice teachers do not necessarily have a shared view of how to best develop a learning plan and impart their knowledge and there is considerable variance in their use of written materials, supervisory formats and balancing theoretical and practical emphases (Wayne et al., 2006). And although the content of most social work programs are governed by formal requirements outlined by the professional bodies, they are limited to accreditation standards, such as required hours and qualifications of supervisors, rather than learning and teaching processes (Raskin et al., 2008; AASW, 2012).

Smith, Cleak \& Vreugdenhil, (2014) developed a learning and assessment tool for common use by seven schools of social work in Australia, and identified seven learning activities that students needed to complete on placement. They included an awareness of values, ethics, and professional practice; an understanding of the organisational, legal, and political contexts; use of theories and methodologies relevant to practice; an ability to form constructive relationships; self-learning and professional development and recognition of research and social policy as an integral part of practice. Similarly, a New Zealand study undertook a content analysis of assessment documents used by six social work programs and found a high level of agreement between the programs about the need to assess skills development and the 
appropriate use of self and supervision, as well as reflective practice, integration of theory and practice, and ethical practice (Hay and O’Donoghue, 2009). In the United States, the 2008 Educational Policy and Accreditation Standards (EPAS) identified ten well-known professional core competencies to address the needs and evaluate the outcomes of student learning (Lyter, 2012).

Some learning activities have been identified as particularly important. Bogo (2006) concluded that students valued their relationship with their supervisor, particularly when they received critical feedback about their practice as well as opportunities to observe practitioners and to have their work observed. Lefevre (2005) conducted a small study into student perceptions of the significance of the supervision on their learning and reported that students referred to the importance of certain tasks carried out by the practice teacher, such as their knowledge, skills and experience in direct teaching, organization/management of the placement and promoting the student's self-reflection on values and personal experience. The practice teacher's ability to identify and link theory to practice appeared particularly important with some students demonstrating frustration that the practice teacher did not demonstrate adequate levels of these skills and abilities. Fortune and colleagues (2001) found that conducting co-interviewing with field instructors and feedback on process recordings were significantly associated with students' perceptions of the quality of supervision in the first practicum; in the second placement, the most significant learning activities were explanations from the field instructor, critiquing one’s own work, making connections to theory, and observing others in professional roles.

There is also an expectation that students develop an ability to think reflectively, and cultivate concepts, such as the "use of self” and "professional demeanour” (Bogo \& Wayne, 2013), but 
creating and preserving the space for reflective practice can be compromised by the prevailing discourse of managerialism found in practice (Chinnery \& Beddoe, (2011).

So while it is recognised that most social work field education programs provide a consistent message about the desirable content of students' learning on placement, the actual practice varies and student feedback suggest considerable variance with the frequency and quality of these learning experiences. This is particularly important given the context of economic and social transformations in Northern Ireland social work education over the last decade and a greater public demand for transparency and accountability within the social work profession (Skehill, 2005; Guerin et al., 2010).

Research aims

The aims of this research were:

1. To identify and describe the different supervision models and structures used in social work student placements

2. To identify the learning experiences and opportunities provided during the social work placements, and how they compared with the accreditation standards

3. To assess how frequently these learning tasks were provided and who provided them

4. To gauge the levels of social work student satisfaction with their practice learning opportunity.

\section{Method}

This study used a cross-sectional survey to explore the experiences and views of social work students from two Irish universities regarding their learning during field placement. Ethical approval was obtained from the School Research Ethics Committee at the School of 
Sociology, Social Policy and Social Work at Queen’s University Belfast, which also covered data collection in Ulster University.

\section{Questionnaire design}

The survey instrument, originally developed for the Australian context (Cleak \& Smith, 2012; Smith et al., (2014) was adapted to reflect the terminology and standards used in the delivery of social work practice learning opportunities (PLOs) in Northern Ireland. The selfadministered, written questionnaire consists of three sections:

Section one: Students were asked to provide brief information relating to their placement, such as the year level, service user group and setting for PLO. Children’s services PLOs include residential and foster care, youth justice, hospital maternity or children's wards and family centres. Adult services PLO include residential, hospital or outreach services in mental health, criminal justice, addictions, dementia, physical health and disability.

Section two: Students were asked to identify their placement supervision structure from four alternatives:

1. A singleton or on on-site practice teacher, who provided both professional social work supervision, and task supervision (Singleton PT);

2. A long-arm practice teacher, who provided professional social work supervision, and a qualified social worker, who was the on-site facilitator and provided day to day caseload supervision (Long-arm OSF qualified);

3. A long-arm practice teacher, who provided professional social work supervision, and an on-site facilitator who was not social work qualified (Long-arm OSF unqualified); or

4. Other, where the supervision structure did not fall under the other three models, with students asked to describe the arrangements for their supervision. 
Section three: Students were asked to record the extent to which they were engaged in sixteen learning activities and who provided that opportunity. To assess competence, students are required to be formally observed working with service users on at least three occasions, they are expected to be supervised weekly (or at least fortnightly) and they must demonstrate competence in relation to six key roles: working with individuals to assess need; review and evaluate social work practice; work with individuals to achieve greater independence; manage risk; be accountable for their work, with supervision and support; demonstrate professional competence in social work practice (DHSSPSNI, 2003) and they must uphold the values of the NISCC Code of Practice for Social Care Workers (NISCC, 2002). The frequency of each of the learning activities was recorded using a four-point Likert scale: 'regularly' - on average at least once per week; 'sometimes' - on average less than once a week but more than once a month; 'rarely' - on average less than once a month but at least once during placement; or 'not at all' - did not receive at all during the practice learning opportunity.

\section{Recruitment and Sampling}

All full-time undergraduate students registered to study social work at Queen’s University Belfast and Ulster University, who had undertaken their first or final PLO between January 2013 and May 2014, were invited to participate in the study. Questionnaires were distributed to students during their final recall day at the respective university campus during their PLO. At least one week prior to the recall day, students were provided with a participant information sheet which offered an explanation of the research project, and informing them that participation was voluntary and that all questionnaires would be returned anonymously. During the data collection period, 708 students completed their social work PLO but not all were able to attend the recall day at the University when recruitment occurred. A total of 396 
students returned a completed questionnaire, representing a strong response rate of 56 per cent.

\section{Data analysis}

Statistical analyses were undertaken using SPSS for Windows (Version 20). The rate of missing data was low for most items, ranging from zero to ten per cent. However, for the two measures of student satisfaction, data were only available for 51 per cent of cases as these measures were included part-way through the data collection period. Missing data were excluded from all analyses. An 'overall regularity of engagement with learning activities' scale score was computed as the sum of the sixteen individual learning activity scores, resulting in a scale with a Cronbach’s alpha coefficient of 0.91, indicating a high level of internal consistency. These computed scale scores were then dichotomised to create two equally sized groups for comparison, with scores below the median classified as 'low regularity' and scores at or above the median classified as 'high regularity'. The responses for the two satisfaction rating variables were also dichotomised into 'satisfied' (strongly agree or agree with the satisfaction statement) and 'not satisfied' (strongly disagree or disagree).

Frequencies and percentages were calculated for all variables. Chi ${ }^{2}$ analyses were conducted to test for associations between both the 'overall regularity of engagement with learning activities' (low or high regularity) and the regularity of engagement with each of the sixteen individual learning activities with: PLO year level; setting; service user group; and supervision model. Multivariate analysis (binary logistic regression) was then used to assess the contribution of PLO year level, setting and supervision model to the overall regularity of engagement with learning activities. Differences in the pattern of responses to the two satisfaction measures were assessed using $\mathrm{Chi}^{2}$ analyses and then t-tests were used to test for 
a difference between satisfied and unsatisfied students in terms of their overall engagement with the learning activities. Statistical significance was set at 95 per cent probability.

\section{Results}

\section{Respondent characteristics}

Of the 396 respondents, 151 (38 per cent) reported on their first PLO and 243 (61 per cent) on their final PLO, with an additional two students undertaking a repeat PLO. As Table 1 shows, just over half of the students undertook a children's services PLO with the remainder in adult services. Overall, two-thirds of students were placed in fieldwork settings, with a higher proportion of students on their first PLO (versus second PLO) placed in day or residential care $(\mathrm{p}<0.001)$. Three models of supervision were recorded by respondents with the majority having either a singleton practice teacher (46 per cent) or a long-arm practice teacher with an on-site social work facilitator (48 per cent). Only 24 students (6 per cent) had a long-arm practice teacher with a non-social work on-site facilitator, with students more frequently offered this model of supervision if they were on their first PLO $(p=0.009)$ or if they were in a day care setting $(\mathrm{p}=0.014)$. There was no association between the service user group (adult or children’s services) and the supervision model or PLO year level (first or second).

$<$ Table 1 about here>

A snapshot of student learning activities on placement

Figure 1 shows that the majority of students regularly engaged (on average at least once per week) with many of the learning activities including: being provided with social work supervision; learning about the role of the team/organisation; discussing and reflecting on 
practice skills; being given constructive feedback about progress; discussing feelings and values about practice; and preparation for learning new tasks/skills. However, even with these 'high-regularity' learning activities it is important to note that there were still many students missing out on regular engagement with them: for example 49 students (13 per cent) did not receive regular social work supervision; and 81 students (21 per cent) were not given constructive feedback about their progress. Also of concern were the ten learning activities which were received regularly by less than three quarters of total students, falling to a low of only 47 per cent for 'linking practice to the NISCC codes of practice'. Moreover, additional analysis revealed that only 61 students (18 per cent) regularly received all sixteen learning activities.

$<$ Figure 1 about here $>$

The 'overall regularity of engagement with the learning activities' score was calculated as the sum of the regularity ratings for all sixteen learning activities, with scores below the median classified as 'low regularity' and scores at or above the median classified as 'high regularity'. The overall regularity score varied according to the type of placement. As Table 2 shows, students on a first placement or in supervision model 'long-arm OSF unqualified' had significantly lower overall engagement with the learning activities; while there were some differences according to PLO setting, these differences were not statistically significant. For some individual learning activities there were differences in the regularity of engagement according to the type of placement. A lower proportion of students on their first PLO (compared with students on their final PLO) reported that they regularly engaged with four of the learning activities (using $\mathrm{Chi}^{2}$ analysis):

- Learn about socio-demographic issues/service user group (46\% vs 61\%; $\mathrm{p}<0.001$ ); 
- $\quad$ Link theory and practice (58\% vs 69\%; $\mathrm{p}=0.002$ );

- $\quad$ Discuss feelings and values about practice (72\% vs $81 \%$; $\mathrm{p}=0.042$ ); and

- $\quad$ Link practice to NISCC codes of practice ( $40 \%$ vs 52\%; $\mathrm{p}=0.032$ ).

There were no differences in relation to the regularity of any of the learning activities by service user group (adult versus children's services). In relation to the PLO setting, fewer students who were located in day care settings reported that they regularly observed practice teacher/staff when compared with students in other PLO settings (53\% vs $67 \%$ respectively, p $=0.001)$. Finally, students with the supervision model 'long arm supervision with an unqualified on-site facilitator' were less likely to engage regularly with four learning activities, when compared with students in the other two supervision models using $\mathrm{Chi}^{2}$ analysis:

- Receiving social work supervision (74\% vs $86 \%$, 91\% respectively; $\mathrm{p}=0.003$ );

- Observe/work with staff (44\% engaged regularly vs 68\%, 67\%; $\mathrm{p}=0.07$ );

- $\quad$ Thinking critically about social work role (48\% vs 72\%, 73\%; p = 0.039); and

- $\quad$ Resources/systems (52\% vs 73\%, 64\%; $\mathrm{p}=0.018)$.

<Table 2 about here>

These results suggest that PLO year level and supervision model both influence the regularity of engagement of students with the learning activities on placement. In particular, it seems that the 'long-arm OSF unqualified' supervision model may be problematic when compared to the other models and that students on their first placement engage less regularly with the learning activities than those on their second placement. Day care placements may also be problematic in providing sufficient opportunities for students to observe social work practice. But what is the contribution of each of these factors to overall engagement with learning 
activities? Using multivariate analysis, year level (first or second) was a significant predictor of overall regularity of engagement with learning activities, with supervision model and placement setting not significant when all variables were included in the analysis (odds ratio $=1.7,95 \% \mathrm{CI}=1.1-2.7, \mathrm{p}=0.028)$. However, caution must be exercised when interpreting this result due to the low number of students in the 'long-arm OSF unqualified' supervision model and day care settings (low event rates). These low event rates also mean that it was not possible to explore interaction effects with these variables.

\section{Who provided the learning activities?}

In addition to exploring the regularity of engagement with specific learning activities, students were asked to indicate who provided these learning activities and how regularly they were assisted with them by these staff. As Table 3 illustrates, social work supervision was the learning activity most commonly provided on a regular basis and it was largely provided by the practice teacher (singleton 42 per cent; long-arm 46 per cent). In addition, 33 per cent of respondents reported regularly receiving social work supervision from their on-site facilitator who was social work qualified, 3 per cent from their on-site facilitator who was not a qualified social worker and 12 per cent from 'other social workers'. In terms of the other learning activities, it is clear from Table 3 that many staff other than practice teachers or formal on-site facilitators regularly assisted students with their learning.

$<$ Table 3 about here>

\section{Student satisfaction}

A subset of 202 students were asked to rate their satisfaction with their PLO. As Table 4 shows, 87 per cent of respondents were satisfied with both the supervision and support 
provided to them on their PLO and the range of learning activities they received. There were no differences in the level of satisfaction on either measure by PLO year level or by PLO setting. However, there were differences on both of the satisfaction measures in terms of models of supervision with significantly more students in the 'long-arm PT, unqualified OSF' model dissatisfied with supervision and support and also the range of learning activities provided on PLO, compared with students in the other two supervision models. Table 4 also indicates that students who were satisfied with placement (on both satisfaction measures) had significantly higher overall regularity of engagement with the learning activities compared with those who were not satisfied. Given the association between the overall regularity of engagement with learning activities and supervision model (Table 2), this suggests a possible link between satisfaction with placement, supervision model and regularity of engagement with learning activities. Again though, the low event rate for the 'long-arm OSF unqualified' supervision model means that it was not possible to reliably explore this interaction further in this study.

$<$ Table 4 about here>

\section{Study limitations}

Although this research was able to obtain a large sample of social work students undertaking their first or final placement, it also had a number of limitations. Students enrolled in the two social work programs in Northern Ireland are generally a homogenous group in terms of gender and age but it would have been interesting to collect some demographic data to explore whether any of these variables could account for some of their responses. The timing of administering the questionnaire was constrained by regionally agreed 'recall days' which were held in the last few weeks of placement so some students may have had a few weeks left 
in their placement when they completed the questionnaire which may have affected their responses. Not all students provided data on their satisfaction with the placement and the questionnaire did not define what was understood by 'time for reflection' or 'supervision'. Additionally, questionnaires were only completed by students who had successfully completed the placement as those students who had been withdrawn from their placement did not attend the recall days. However, they only accounted for a very small percentage of the potential pool of students.

\section{Discussion}

This study recruited students from the two regional universities teaching social work in Northern Ireland who reported on their supervision arrangements and the range of learning experiences that occurred during their placement and who provided them. The study identified three models of supervision that were used in field education, although the overwhelming majority of students received either on-site supervision or 'long arm' supervision in almost equal numbers which reaffirms the value that is still attached to students having their placement with a primary social work supervisor present onsite.

However, a different pattern emerges when the student reported on who actually provided the learning activity on a regular basis. Another supervision model, where one or more social work supervisors shared the education and supervision of the student, was identified from the student responses, with over a third of the supervision being provided by a range of other agency staff apart from the singleton or long arm supervisor. Although students indicated that all staff contributed to their learning journey, the results indicate that it was 'other social workers within the team' who most frequently assisted with the learning in significant areas that are emphasised in the Northern Ireland Framework Specification (DHSSPSNI, 2003). 
This finding substantiates the results of two other studies on supervision models study which confirms the teaching and learning benefits of sharing the responsibility for providing learning opportunities for students (Cleak \& Smith, 2012; Coulton and Krimmer, 2005). These emerging structures could offer some evidence to create a feasible alternative for agencies wanting to offer a practice learning experience within a climate of shrinking welfare budgets and increasing workloads (Wilson et al., 2008).

The study also highlighted that the frequency of learning activities vary according to different settings, year levels and who provided the learning. In keeping with the Practice Learning Requirements for the Degree in Social Work (NISCC, 2010), final year students were more likely to have a social work qualified onsite supervisor and to be exposed to more complex learning activities and critical reflection, which differed to first year PLO students. First year PLO students were more likely to have long arm supervision, an unqualified on-site facilitator and to be placed in day care or supported living settings where there were fewer opportunities to work directly with social workers or in a social work role. Interestingly, the final year students in the Australian study also reported that they were more satisfied with the learning experiences offered (Cleak \& Smith, 2012).

The key questions that arise from these findings include what does the social work profession expect to be the key learning activities that are essential for the development of acquisition of the necessary knowledge, skills and values? Although reflective practice was a frequent activity, it was concerning that over a third of students did not regularly have the opportunity to observe social work practice, have their practice observed, or to link social work theory and the NISCC Code to their practice with their social work supervisor. Interestingly, these results are the same learning areas that were found to be less frequently provided in the original Australian study with an even larger percentage of students not having the opportunity to have their practice observed (66\%), linking practice to the Code of Ethics, 
(53\%), linking theory to practice (51\%) or observing other worker's practice (46\%). The low rate of these activities being provided in these two large scale studies raises some important questions, especially when modelling and feedback of practice has been identified as an essential and useful learning strategy to promote social work identity and competence (Fortune et al., 2001; Maidment, 2003; DHSSPSNI, 2010) and are recognised by both accreditation bodies as essential learning tasks AASW, 2012: 5; NISCC, 2002).

Social work supervisors should actively look for opportunities to broach pertinent ethical issues such as confidentiality and privacy, informed consent and boundary issues. Social work students should fully understand the nature of clients’ rights and become familiar with agencies’ policies as well as the profession's ethical guidelines (Anastas, 2008; NASW, 2008; NISCC, 2002). Why supervisors fail to provide these opportunities could be related to their own waning adherence to these principles which become superseded by organisational priorities as well as balancing the competing demands of supervising students with no workload relief amidst an economic climate of dwindling resources and increasing caseloads. Muskat et al., (2012) also identified the pressure on community teams trying to educate and supervise more students without workload reduction.

The majority of participants identified a high level of satisfaction with the supervision and support they received during their placement and the results of the satisfaction with support, supervision and learning opportunities were consistent across students who had a singleton or a long-arm practice teacher with a qualified onsite facilitator. However, a significant difference was found in satisfaction with levels of support and supervision from students who had an unqualified on-site facilitator. Our findings revealed that this latter group were less likely to receive social work supervision, observe social work staff or think critically about social work. Presently, the NISCC Regional Strategy (2010) indicates that first placement 
students only require experience of working alongside social work practitioners whereas final year students must have a social work practitioner based onsite. The subsequent gaps in learning opportunities and supervision for students who do not have regular access to social work colleagues may prompt a review of the NISCC criteria and raise concerns that some practice placements may not be fully preparing students for the workforce (DHSSPSNI, 2010; The College of Social Work, 2012). Findings in other research illustrated that a strong social work presence in the PLO site resulted in higher levels of student satisfaction (Cleak \& Smith, 2012); that students welcomed frequent and longer supervision sessions (Knight, 2001); and that students responded positively to learning activities that provided opportunities to see and work with professional role models (Fortune et al, 2001).

Given the importance that social work programs and accreditation bodies attribute to the content and processes field education programs to socialise students into the profession, it is concerning that many students are not receiving a number of critical learning activities regularly. Some of the ongoing debates and need for future research questions includes what constitutes a valid site of learning for social work and how minimum standards are defined and evaluated and when an agency is deemed unsuitable to provide a quality placement (Bellinger, 2010). It may be important to investigate whether students actually value the same suite of learning tasks to facilitate the development of their professional knowledge and skills and to further explore what students understand by or believe they need in relation to supervision during placements. It would also be helpful to conduct focus groups with students and practice teachers to capture the different perceptions of how supervision is conducted and why some tasks, such as reflection on practice, discussing the Code of Ethics and observing students in practice. 
Anastas, J. W. (2010) Teaching in social work: An Educators' guide to theory and practice, New York, Columbia University Press.

Australian Association of Social Workers (AASW) (2012) Australian social work education and accreditation standards, Available at: http://www.aasw.asn.au/document/item/3136.

Bellinger, A. (2010) 'Studying the Landscape: Practice Learning for Social Work Reconsidered', Social Work Education, 29(6), pp. 599 - 615.

Bogo, M. (2006) 'Field instruction in social work: A review of the research literature’ The Clinical Supervisor, 24(1-2), pp. 163-193.

Bogo, M. and Wayne, J. (2013) 'The implicit curriculum in social work education: The culture of human interchange', Journal of Teaching in Social Work, 33(1), pp. 2-14.

Bogo, M., Regehr, C., Woodford, M., Hughes, J., Power, R. and Regehr, G. (2006) ‘Beyond competencies: Field instructors’ descriptions of student performance', Journal of Social Work Education, 42(3), pp. 579-594.

Bogo, M., Regehr, C., Hughes, J., Power, R. and Globerman, J. (2002) 'Evaluating a measure of student field performance', Journal of Education for Social Work, 38(3), pp. 385-401.

Chinnery, S. A. and Beddoe, L. (2011) 'Taking active steps towards the competent use of self in social work’ Advances in Social Work and Welfare Education, 13(1), pp. 89-106. 
Cleak, H., Hawkins, L., \& Hess, L. (2000) ‘Innovative Field Options’, in L. Cooper and L. Briggs, (eds) Fieldwork in the Human Services, Allen and Unwin, Adelaide, 160-174.

Cleak, H. \& Smith, D. (2012) 'Student satisfaction with current models of field placement supervision’, Australian Social Work, 65, 2, 243-258

Coulton, P. and Krimmer, L. (2005) 'Co-supervision of social work students: A model for meeting the future needs of the profession', Australian Social Work, 58 (2), pp. 154-166.

Council on Social Work Education (2008) Education Policy and Accreditation Standards, Available at: http://www.cswe.org/Accreditation/2008EPASDescription.aspx

Croisdale-Appleby (2014) 'Re-visioning social work education. An independent review'. London: Department of Health (2014).

Department of Health, Social Services and Public Safety (2003) Northern Ireland Framework Specification for the Degree in Social Work, Belfast, DHSSPSNI, Available at: http://www.dhsspsni.gov.uk/dhssps_sociawork_doc.pdf

Department of Health, Social Services and Public Safety (2010) Degree in Social Work: A regional Strategy for Practice Learning Provision in Northern Ireland 2010-2015, Belfast, DHSSPSNI, Available at: http://www.niscc.info/files/Degree\%20in\%20Social\%20Work/2010Apr_PracticeLearning Strategy2010-15_Report_ApprovedAFMCK1.pdf 
Fortune, A., McCarthy, M. and Abramson, J. (2001) 'Student learning processes in field education: Relationship of learning activities to quality of field instruction, satisfaction, and performance among MSW students', Journal of Social Work Education, 37(1), pp. 111-124.

Freddolino, P., Groden, S., Navarre, J., McFall, J., Toler Woodward, A. and Jahr, A. (2014) ‘Using Field Evaluation Data for Continuous Quality Improvement: A Policy Competency Example”, The Field Educator, 4 (2), pp. 1-14.

Furness, S. and Gilligan, P. (2004) 'Fit for purpose: Issues from practice placements, practice teaching and the assessment of students' practice', Social Work Education: The International Journal, 23 (4), pp. 465-479.

Gough, H. and Wilks, S. (2012) 'Rotational Field Placements: Integrative Review and Application to Gerontological Social Work', Social Work Education: The International Journal, 31(1), pp, 90-109.

Globerman, J. and Bogo, M. (2002) 'The impact of hospital restructuring on social work field Education', Health and Social Work, 27(1), pp. 7-16.

Guerin, S., Devitt, C. and Redmond, B. (2010) ‘Experiences of Early-Career Social Workers in Ireland', British Journal of Social Work, 40(8), pp. 2467-2484. 
Hay, K. and O’Donoghue, K. (2009) ‘Assessing social work field education: Towards standardising fieldwork assessment in New Zealand’ Social Work Education: The International Journal, 28(1), pp. 42-53.

Knight, C. (2000) 'Engaging the student in the field instruction relationship: BSW and MSW students’ views’, Journal of Teaching in Social Work, 20(3-4), pp. 173-201.

Knight, C. (2001) 'The process of field instruction: BSW and MSW students' views of effective field supervision', Journal of Social Work Education, 37(2), pp. 357-379.

Lefevre, M. (2005) ‘Facilitating Practice Learning and Assessment: The Influence of Relationship’, Social Work Education, 24(5), pp. 565-583.

Lyter, S. C. (2012) 'Potential of field education as signature pedagogy: The field director role’, Journal of Social Work Education, 48(1), pp. 179-188.

Maidment, J. (2003) 'Problems experienced by students on field placement: using research findings to inform curriculum design and content', Australian Social Work, 56 (1), pp. 50-60.

Maidment, J. and Woodward, P. (2002) 'Student supervision in Context. A model for external supervision’ In Shardlow, S. and Doel, M. Learning to practice social work: International approaches, London, Jessica Kingsley Publishers.

McMahon, M. and Patton, W. (eds.) Supervision in the helping professions a practical approach, Frenchs Forest, NSW: Pearson Education Australia, pp. 91-104. 
Muskat, B., Bogo, M. and Perlman, I. (2012) 'Making rotational field placements work: Review of a successful pilot of rotational field placements in hospital settings', Journal of Practice Teaching and Learning, 11(1), pp. 5-18.

Narey, M. (2014) 'Making the education of social workers consistently effective', Report of Sir Martin Narey’s independent review of the education of children’s social workers.

National Association of Social Workers (2008) Code of Ethics. Washington, DC, NASW.

Northern Ireland Social Care Council (2010) Practice learning requirements for the Degree in Social Work, Belfast, NISCC Available at: http://www.niscc.info/files/Degree\%20in\%20Social\%20Work/2011Jan_PLRequirements DegSWReprintedAug2010_Publication_Approved_AFMCK.pdf

Northern Ireland Social Care Council (2002) Code of Practice for Social Care Workers and Employers of Social Care Workers, Belfast, NISCC Available at: http://www.niscc.info/files/Codes/2010Jun_CodesOfPracticeLargePrint_report_Approved AFMCK.pdf

Ortiz-Hendricks, C., Finch, J. B., and Franks, C. L. (2005) Learning to teach, teaching to learn: A guide for social work field education. Alexandra, VA: Council on Social Work Education.

Plath, D. (2003) ‘An experience based model for practice learning', The Journal of Practice Teaching and Learning, 5, pp. 23-38 
Raskin, M., Wayne, J. and Bogo, M. (2008) ‘Revisiting field education standards’ Journal of Social Work Education Standards, 44(2), pp. 173-188.

Regehr, C. (2013) 'Trends in higher education in Canada and implications for social work education', Social Work Education: The International Journal, 32(6), pp. 700-714.

Skehill, C. (2005) 'Child protection and welfare social work in the Republic of Ireland: Continuities and discontinuities between the past and the present', in Kearney, N. and Skehill, C. (eds), Social Work in Ireland: Historical Perspectives, Dublin, Institute of Public Administration, pp. 127-46.

Smith, D., Cleak, H. and Vreugdenhil, A. (2014) 'What are they Really Doing? An exploration of student learning activities in field placement', Australian Social Work, Advance Access published November 12, 2014, doi: 10.1080/0312407X.2014.960433.

The College of Social Work (2012) Quality Assurance in Practice Learning, $2^{\text {nd }}$ edition, London.

Ung, K. (2002) ‘The complex and diverse landscape of agency and external supervision’. In M. McMahon \& W. Patton (Eds.), Supervision in the helping profession: A practical approach, Frenches Forest: Pearson Education Australia, pp. 91-104. 
Wayne, J., Bogo, M. and Raskin, M. (2006) ‘The need for radical change in field education’ Journal of Social Work Education, 42(1), pp. 161-169.

Wayne, J., Raskin, M. and Bogo, M. (2010) 'Field education as the signature pedagogy of social work education', Journal of Social Work Education, 46(3), pp. 327-339.

Wilson, G., Walsh, T. and Kirby, M. (2008) ‘Developing practice learning: Student perspectives’, Social Work Education, 27(1), pp. 35-50.

Zuchowski, I. (2015) 'Being the University: Liaison Persons' Reflections on Placements with OffSite Supervision', Social Work Education: The International Journal, DOI: $10.1080 / 02615479.2015 .1005070$ 
Table 1 Characteristics of the practice learning context

\begin{tabular}{llccc}
\hline Category & First PLO & $\begin{array}{c}\text { Second } \\
\text { PLO }\end{array}$ & Total* \\
\hline Service user group & Adult Services & $73(49 \%)$ & $104(44 \%)$ & $177(46 \%)$ \\
& Children's services & $75(51 \%)$ & $134(56 \%)$ & $209(54 \%)$ \\
\cline { 2 - 4 } & Total & $148(100 \%)$ & $238(100 \%)$ & $386(100 \%)$ \\
\hline Setting & Fieldwork & $86(58 \%)$ & $174(73 \%)$ & $260(67 \%)$ \\
& Day Care & $17(11 \%)$ & $3(1 \%)$ & $20(5 \%)$ \\
& Residential & $34(23 \%)$ & $30(13 \%)$ & $64(16 \%)$ \\
& Hospital & $8(5 \%)$ & $18(7 \%)$ & $26(7 \%)$ \\
& Other & $4(3 \%)$ & $14(6 \%)$ & $18(5 \%)$ \\
\cline { 2 - 5 } & Total & $149(100 \%)$ & $239(100 \%)$ & $388(100 \%)$ \\
\hline Supervision model & Singleton PT & $62(41 \%)$ & $119(49 \%)$ & $181(46 \%)$ \\
& Long-arm PT,OSF qualified & $73(48 \%)$ & $114(47 \%)$ & $187(48 \%)$ \\
& Long-arm PT, OSF unqualified & $16(11 \%)$ & $8(3 \%)$ & $24(6 \%)$ \\
\cline { 2 - 3 } & Total & $151(100 \%)$ & $241(100 \%)$ & $392(100 \%)$ \\
\hline
\end{tabular}

*total $\mathrm{N}$ varies as a small number of students did not complete all questions

Table 2 Total regularity of engagement with learning activities by placement type

\begin{tabular}{lrrr}
\hline & $\begin{array}{l}\text { Low overall } \\
\text { regularity }\end{array}$ & $\begin{array}{l}\text { High overall } \\
\text { regularity }\end{array}$ & \multicolumn{1}{l}{ Total } \\
\hline PLO year level $^{* *}$ & & & \\
First & $82(59 \%)$ & $58(41 \%)$ & $140(100 \%)$ \\
Second & $86(44 \%)$ & $109(56 \%)$ & $195(100 \%)$ \\
PLO supervision model $^{*}$ & & & \\
Singleton PT & $65(44 \%)$ & $83(56 \%)$ & $148(100 \%)$ \\
Long-arm OSF qualified & $88(53 \%)$ & $77(47 \%)$ & $165(100 \%)$ \\
Long-arm OSF unqualified & $16(70 \%)$ & $7(30 \%)$ & $23(100 \%)$ \\
PLO setting & & & \\
Fieldwork & $109(49 \%)$ & $113(51 \%)$ & $222(100 \%)$ \\
Day care & $10(62 \%)$ & $6(38 \%)$ & $16(100 \%)$ \\
Residential & $30(52 \%)$ & $28(48 \%)$ & $58(100 \%)$ \\
Hospital & $9(41 \%)$ & $13(59 \%)$ & $22(100 \%)$ \\
Other & $10(62 \%)$ & $6(38 \%)$ & $16(100 \%)$ \\
\hline
\end{tabular}


${ }^{*} \mathrm{p}<0.05$ using $\mathrm{Chi}^{2}$ analysis; ${ }^{* *} \mathrm{p}<0.01$ using $\mathrm{Chi}^{2}$ analysis

Table 3 Who provided the learning activities?

\begin{tabular}{|c|c|c|c|c|c|}
\hline \multirow[b]{2}{*}{ Learning activity } & \multicolumn{5}{|c|}{$\begin{array}{l}\text { Students were assisted 'regularly' with this task by } \\
\text { (total } N=396 \text { )*: }\end{array}$} \\
\hline & $\begin{array}{l}\text { Singleton } \\
\text { practice } \\
\text { teacher }\end{array}$ & $\begin{array}{l}\text { Long-arm } \\
\text { practice } \\
\text { teacher }\end{array}$ & $\begin{array}{l}\text { On-site } \\
\text { facilitator }\end{array}$ & $\begin{array}{l}\text { Other } \\
\text { SW } \\
\text { staff }\end{array}$ & $\begin{array}{l}\text { Other } \\
\text { agency } \\
\text { staff }\end{array}$ \\
\hline $\begin{array}{l}\text { Provided with social work } \\
\text { supervision }\end{array}$ & $\begin{array}{c}166 \\
(42 \%)\end{array}$ & $\begin{array}{c}183 \\
(46 \%)\end{array}$ & $\begin{array}{c}143 \\
(36 \%)\end{array}$ & $\begin{array}{c}47 \\
(12 \%)\end{array}$ & $\begin{array}{c}24 \\
(6 \%)\end{array}$ \\
\hline $\begin{array}{l}\text { Learn about role/function } \\
\text { of the team/organisation }\end{array}$ & $\begin{array}{c}174 \\
(44 \%)\end{array}$ & $\begin{array}{c}163 \\
(41 \%)\end{array}$ & $\begin{array}{c}174 \\
(44 \%)\end{array}$ & $\begin{array}{c}232 \\
(59 \%)\end{array}$ & $\begin{array}{c}145 \\
(37 \%)\end{array}$ \\
\hline $\begin{array}{l}\text { Discuss and reflect on } \\
\text { practice skills }\end{array}$ & $\begin{array}{c}150 \\
(38 \%)\end{array}$ & $\begin{array}{c}174 \\
(44 \%)\end{array}$ & $\begin{array}{c}140 \\
(35 \%)\end{array}$ & $\begin{array}{c}84 \\
(21 \%)\end{array}$ & $\begin{array}{c}44 \\
(11 \%)\end{array}$ \\
\hline $\begin{array}{l}\text { Given constructive } \\
\text { feedback about progress }\end{array}$ & $\begin{array}{c}150 \\
(38 \%)\end{array}$ & $\begin{array}{c}173 \\
(44 \%)\end{array}$ & $\begin{array}{c}153 \\
(39 \%)\end{array}$ & $\begin{array}{c}85 \\
(21 \%)\end{array}$ & $\begin{array}{c}51 \\
(13 \%)\end{array}$ \\
\hline $\begin{array}{l}\text { Discuss feelings and } \\
\text { values about practice }\end{array}$ & $\begin{array}{c}151 \\
(38 \%)\end{array}$ & $\begin{array}{c}165 \\
(42 \%)\end{array}$ & $\begin{array}{c}148 \\
(37 \%)\end{array}$ & $\begin{array}{c}95 \\
(24 \%)\end{array}$ & $\begin{array}{c}47 \\
(12 \%)\end{array}$ \\
\hline $\begin{array}{l}\text { Discuss and prepare for } \\
\text { learning new tasks/skills }\end{array}$ & $\begin{array}{c}148 \\
(37 \%)\end{array}$ & $\begin{array}{c}154 \\
(39 \%)\end{array}$ & $\begin{array}{c}148 \\
(37 \%)\end{array}$ & $\begin{array}{c}119 \\
(30 \%)\end{array}$ & $\begin{array}{c}59 \\
(15 \%)\end{array}$ \\
\hline $\begin{array}{l}\text { Think critically and } \\
\text { reflectively about SW role }\end{array}$ & $\begin{array}{c}147 \\
(37 \%)\end{array}$ & $\begin{array}{c}162 \\
(41 \%)\end{array}$ & $\begin{array}{c}118 \\
(30 \%)\end{array}$ & $\begin{array}{c}76 \\
(19 \%)\end{array}$ & $\begin{array}{c}32 \\
(8 \%)\end{array}$ \\
\hline $\begin{array}{l}\text { Learn about legislation, } \\
\text { policies and procedures }\end{array}$ & $\begin{array}{c}127 \\
(32 \%)\end{array}$ & $\begin{array}{c}146 \\
(37 \%)\end{array}$ & $\begin{array}{c}135 \\
(34 \%)\end{array}$ & $\begin{array}{c}117 \\
(29 \%)\end{array}$ & $\begin{array}{c}62 \\
(16 \%)\end{array}$ \\
\hline $\begin{array}{l}\text { Learn about resources, } \\
\text { systems \& networks }\end{array}$ & $\begin{array}{c}134 \\
(34 \%)\end{array}$ & $\begin{array}{c}118 \\
(30 \%)\end{array}$ & $\begin{array}{c}137 \\
(35 \%)\end{array}$ & $\begin{array}{c}151 \\
(38 \%)\end{array}$ & $\begin{array}{c}86 \\
(22 \%)\end{array}$ \\
\hline $\begin{array}{l}\text { Observe practice } \\
\text { teacher/staff }\end{array}$ & $\begin{array}{c}120 \\
(30 \%)\end{array}$ & $\begin{array}{c}88 \\
(22 \%)\end{array}$ & $\begin{array}{c}143 \\
(36 \%)\end{array}$ & $\begin{array}{c}146 \\
(37 \%)\end{array}$ & $\begin{array}{c}73 \\
(18 \%)\end{array}$ \\
\hline Link theory and practice & $\begin{array}{c}134 \\
(34 \%)\end{array}$ & $\begin{array}{c}153 \\
(39 \%)\end{array}$ & $\begin{array}{c}109 \\
(28 \%)\end{array}$ & $\begin{array}{c}69 \\
(15 \%)\end{array}$ & $\begin{array}{c}38 \\
(10 \%)\end{array}$ \\
\hline $\begin{array}{l}\text { Have practice observed by } \\
\text { practice teacher/staff }\end{array}$ & $\begin{array}{c}120 \\
(30 \%)\end{array}$ & $\begin{array}{c}87 \\
(22 \%)\end{array}$ & $\begin{array}{c}118 \\
(30 \%)\end{array}$ & $\begin{array}{c}98 \\
(25 \%)\end{array}$ & $\begin{array}{c}60 \\
(15 \%)\end{array}$ \\
\hline $\begin{array}{l}\text { Learn about socio- } \\
\text { demographic issues/ } \\
\text { service user group }\end{array}$ & $\begin{array}{c}111 \\
(28 \%)\end{array}$ & $\begin{array}{c}116 \\
(29 \%)\end{array}$ & $\begin{array}{c}133 \\
(34 \%)\end{array}$ & $\begin{array}{c}147 \\
(37 \%)\end{array}$ & $\begin{array}{c}102 \\
(26 \%)\end{array}$ \\
\hline $\begin{array}{l}\text { Link tasks with practice } \\
\text { foci and key roles }\end{array}$ & $\begin{array}{c}103 \\
(26 \%)\end{array}$ & $\begin{array}{c}131 \\
(33 \%)\end{array}$ & $\begin{array}{c}75 \\
(19 \%)\end{array}$ & $\begin{array}{c}42 \\
(11 \%)\end{array}$ & $\begin{array}{c}20 \\
(5 \%)\end{array}$ \\
\hline $\begin{array}{l}\text { Provided with reading } \\
\text { materials and theory }\end{array}$ & $\begin{array}{c}104 \\
(26 \%)\end{array}$ & $\begin{array}{c}117 \\
(30 \%)\end{array}$ & $\begin{array}{c}74 \\
(19 \%)\end{array}$ & $\begin{array}{c}57 \\
(14 \%)\end{array}$ & $\begin{array}{c}35 \\
(9 \%)\end{array}$ \\
\hline $\begin{array}{l}\text { Link practice to NISCC } \\
\text { codes of practice }\end{array}$ & $\begin{array}{c}94 \\
(24 \%)\end{array}$ & $\begin{array}{c}105 \\
(26 \%)\end{array}$ & $\begin{array}{c}81 \\
(20 \%)\end{array}$ & $\begin{array}{c}41 \\
(10 \%)\end{array}$ & $\begin{array}{c}24 \\
(6 \%)\end{array}$ \\
\hline
\end{tabular}

* Students could be assisted with LA by more than one category of staff 
Table 4 Student satisfaction with the supervision models

\begin{tabular}{|c|c|c|c|c|c|}
\hline & \multicolumn{2}{|c|}{$\begin{array}{l}\text { Satisfied with supervision } \\
\text { and support }\end{array}$} & \multicolumn{2}{|c|}{$\begin{array}{c}\text { Satisfied with range } \\
\text { of learning }\end{array}$} & \multirow[t]{2}{*}{ Total } \\
\hline & Satisfied & Not satisfied & Satisfied & Not satisfied & \\
\hline \multicolumn{6}{|l|}{ Supervision model } \\
\hline Singleton PT & $82(87 \%)$ & $12(13 \%)$ & $83(88 \%)$ & $11(12 \%)$ & $94(100 \%)$ \\
\hline Long-arm OSF qualified & $84(90 \%)$ & $10(10 \%)$ & 84 (89\%) & $10(11 \%)$ & $94(100 \%)$ \\
\hline Long-arm OSF unqualified & $9(64 \%)$ & $5(36 \%)$ & $9(64 \%)$ & $5(36 \%)$ & $14(100 \%)$ \\
\hline Total & $175(87 \%)$ & $27(13 \%)^{*}$ & $176(87 \%)$ & $26(13 \%)^{*}$ & $202(100 \%)$ \\
\hline $\begin{array}{l}\text { Overall regularity of } \\
\text { engagement score/ } 64 \\
\text { (mean, SD) }\end{array}$ & $41.5(6.04)$ & $33.8(13.14)^{* * *}$ & $41.0(6.86)$ & $37.3(12.14)^{* *}$ & \\
\hline
\end{tabular}

${ }^{*} \mathrm{p}<0.05$ using $\mathrm{Chi}^{2}$ analysis; ${ }^{* *} \mathrm{p}<0.01$ using t-test; *** $\mathrm{p}<0.001$ using t-test 